\title{
Overcoming the legal hurdles involved in hedge fund investments
}

Received: 27th February, 2004

\section{Simon Atiyah}

graduated in law in 1982, was admitted as a solicitor in England in 1985 and is currently a partner in Lovells' London office. Simon has also practised, and is admitted as a lawyer, in Hong Kong and Bermuda and specialises in the law and practice relating to collective investment schemes.

\begin{abstract}
This paper examines the issues involved for pension funds and institutional investors when investing in hedge funds, looks at the legal structure of a typical hedge fund and examines the structural issues that arise when investing in such products. The paper also considers some of the terms upon which such investments are made and briefly looks at possible future developments in the field.
\end{abstract}

Keywords: hedge funds; collective investment schemes; admissibility; investment terms; investment managers; taxation

\section{Introduction}

The global hedge fund market is undergoing significant growth and change. Hedge funds, funds of hedge funds and hedge fund based structured products are becoming increasingly popular with investors, and the type and range of investors effecting hedge fund investments is growing. The global hedge fund industry is estimated to be worth between US $\$ 400$ and US $\$ 500$ bn and is growing at a rate of approximately 20 per cent p.a. with roughly 7,000 active hedge funds currently in existence. ${ }^{1}$ Accordingly, hedge funds are no longer the preserve of a small number of select high net worth investors.

Simon Atiyah

Lovells, Atlantic House, Holborn Viaduct, London EC1 2FG, UK.

Tel: +44 (0)22 7296 2000; Fax: +44 (0)20 7296 2001; e-mail:

simon.atiyah@lovells.com
Institutions are recognising that well-balanced investment portfolios should include an exposure to alternative investments, including hedge funds; indeed in the current climate of uncertainty affecting the world's equity markets, one could argue that the institutions have a positive obligation to at least consider diversification of their portfolios into hedge funds and other alternative investments.

Against this background of increasing institutional investment in hedge funds, this paper considers the main legal issues involved in institutional investment in hedge funds. First, it examines the structural considerations involved in undertaking such an investment, and secondly, it covers some of the detailed terms which should be considered in making such an investment.

\section{What is a hedge fund?}

This paper intends to cover investment in what might popularly be described as 'hedge funds'. It is recognised, however, that there is no statutory, regulatory or judicial definition of 'hedge fund' in 
English Law. Hedge funds will generally be 'collective investment schemes' as defined in the Financial Services and Markets Act 2000 (FSMA) as they are 'arrangements with respect to property ... the purpose or effect of which is to enable persons taking part in the arrangements ... to participate in or receive profits or income arising from the acquisition, holding, management or disposal of the property ....2 There is no finite list that distinguishes 'hedge funds' from other forms of collective investment scheme, but last year's UK Financial Services Authority's (FSA's) discussion paper on hedge funds ${ }^{3}$ noted that most hedge funds would have several of the following characteristics.

- Hedge funds are typically offshore investment corporations or investment partnerships.

- They use a wide variety of trading strategies including position taking in a range of markets.

- They employ an assortment of trading techniques and instruments, often including short selling, derivatives and leverage.

- They pay performance fees to their investment managers/advisers.

- They have an investor base comprising wealthy individuals and institutions and a relatively high minimum investment limit (typically set at $\$ 100,000$ or higher).

One should probably add to this list the fact that hedge funds would typically deposit their cash and investments with a bank or broker (prime broker) as security for their underlying trades, whereas other investment funds would deposit their cash and investments with a trustee or custodian bank to be held on trust for the fund or its investors.

Hedge funds are almost universally 'unregulated schemes'. ${ }^{4}$ It is not necessarily the case, however, that all hedge funds pursue 'riskier' investment policies than other funds. In fact, many hedge funds seek to hedge against market downturns in an attempt to reduce volatility and risk. From an investment perspective, many hedge funds are less risky and less volatile than more traditional collective investment schemes. The investment techniques and strategies adopted by hedge fund managers typically give rise to the assumption of certain risks that do not apply to traditional investment funds. Accordingly, hedge funds have a different risk profile as compared to traditional collective investment schemes even though they are not inherently 'riskier' products.

\section{Domicile and structure of hedge funds}

Almost all UK-managed hedge funds are domiciled in offshore zero-rated tax jurisdictions. The Cayman Islands has, historically, been the preferred jurisdiction as it combines a flexible regulatory regime with its zero-tax environment. Other chosen jurisdictions include the Channel Islands, the Isle of Man, Bermuda and the British Virgin Islands. Within the EU, Ireland has become the domicile of choice.

Although most UK-managed hedge funds may be domiciled in the Cayman Islands, very little real activity occurs in that jurisdiction. The fund would typically contract out its management to the UK-based fund manager, while administration would be contracted out to a specialist hedge fund administrator in or near the same time zone as the manager. A sophisticated and extensive hedge fund administration industry has developed, in particular in Dublin, where specialist providers administer hedge funds domiciled in the Cayman Islands and which are managed from London. 


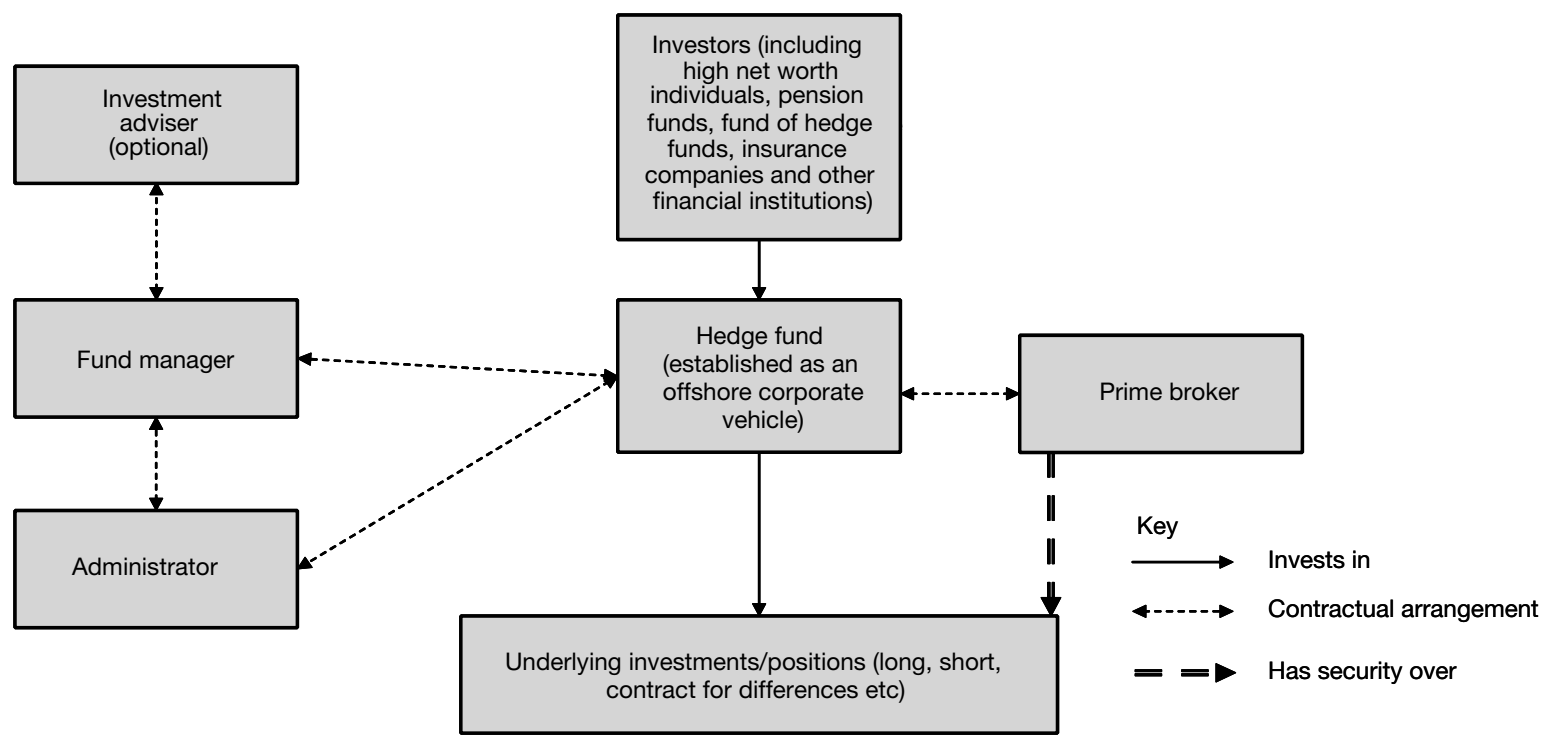

Figure 1: A corporate hedge fund structure

The typical hedge fund is structured in a similar manner to any other offshore collective investment scheme and a corporate hedge fund structure is illustrated in Figure 1 above.

Typically, UK-managed hedge funds will be established as corporate vehicles. Conversely, many US hedge funds have been established as limited partnerships and the more sophisticated hedge funds, which are targeting US tax paying investors, US tax exempt investors and other international investors, would typically adopt 'Master/Feeder' structures whereby investors would be given the choice of investing in the underlying hedge fund either through a corporate structure or through a limited partnership structure.

\section{Structural issues involved in hedge fund investment}

\section{Permissibility and admissibility issues}

The first question which any institution must consider when seeking to make hedge fund investments is whether it falls within their mandate and/or the terms of their constitution. Institutions may be limited or restricted in their ability to invest in collective investment schemes that are not regulated under the FMSA or equivalent European regulations. Some funds may be restricted or limited in their ability to invest in unlisted securities, non-EU entities, or in unregulated tax-free jurisdictions.

A hedge fund product may technically be a permissible investment for an institution, but will probably not be treated as a 'permitted link' and may not be treated as admissible for capital or valuation purposes or have disadvantageous treatment for those purposes. This may well be the case for life and insurance funds where the admissibility of unregulated collective investment schemes is problematic. ${ }^{5}$

Many of the investment banks are active in providing structured products and otherwise repackaging hedge funds to overcome some of these problems. For example, if an institution is unable or unwilling to invest in a particular hedge fund directly, it may be possible to structure the investment by entering into a total return swap contract with an 
investment bank (which in turn would hedge its exposure through direct investment in the hedge fund), or through repackaging the hedge fund investment through a special purpose vehicle (SPV) which could, for example, issue debt or bonds whose return was linked to the relevant hedge fund. These and various other techniques can result in a re-characterisation of the relevant investment such that it would be treated, for example, as debt or as a derivative contract entered into with a potentially rated or approved counterparty, rather than comprising units in an unregulated collective investment scheme. In this way the permissibility and admissibility of the relevant investment may be altered in a way which is advantageous to the investing institution.

\section{Regulatory status}

Even in cases where technical permissibility and admissibility issues of a hedge fund investment are overcome, the prudent pension fund or institutional fund manager should still consider its policy in relation to investment in unregulated products. In formulating policies in this regard, there are a number of factors that could be considered. As we have seen, from a UK perspective the fund itself will always be 'unregulated'. However, the jurisdictions in which hedge funds are domiciled vary considerably in the level of regulation and supervision that they impose. The Cayman Islands has a very 'light touch' regulatory process whereas the regime in Ireland is somewhat more rigorous. Other jurisdictions such as the Channel Islands and Bermuda probably fall somewhere in between these two examples. A further factor is the regulatory status of the manager and other service providers to the hedge fund. Although a UK-managed hedge fund itself may not be regulated in the UK, the UK manager, any UK prime broker and any UK distributor/promoter of the fund in the UK should be regulated. This may give a pension fund investor a degree of comfort that would not be available if, for example, the hedge fund and the manager itself were established in a tax haven or other unregulated jurisdictions. Similarly, the pension fund manager may gain more comfort if the relevant fund has in effect opted for some degree of regulation by seeking a listing for its shares on a recognised stock exchange (it is becoming more common for UK-managed hedge funds to seek a listing on the Irish Stock Exchange). All these factors should be considered by the prudent pension fund manager in determining the acceptability of, and the level of due diligence required in respect of, a particular hedge fund investment.

\section{Limited liability issues}

All investors in hedge funds will, of course, be particularly keen to ensure that the investment is a limited liability investment. The different risk profiles of hedge funds compared to traditional collective investment schemes tend to mean that, particularly with highly geared hedge funds, the risk of insolvency of the hedge fund is less remote than that which would apply to traditional long-only funds. Such insolvency could result not only from mismanagement of the hedge fund itself, but also from a significant counterparty default or the insolvency of the fund's prime or clearing broker. Hence it is doubly important that an investor's investment in a hedge fund is a limited liability investment and that on any insolvency of the hedge fund, creditors could not pursue the investors.

Generally speaking, where the hedge 
fund is established in corporate form, or where the investor can opt to acquire his interest through a corporate vehicle, it should be fairly straightforward to ensure the limited liability nature of the investment. More care, however, should be taken in the case of hedge fund investments that are structured as limited partnerships or unit trusts. In the case of unit trusts, it is important to ensure that the terms of the relevant trust deed do not (either explicitly or implicitly) provide for beneficiaries to indemnify the trustee beyond the amount paid up on any units. Where trust deeds are silent on this issue, there may well be an implied indemnity in favour of the trustee and, in these circumstances, investors should seek express confirmation from the trustee that they would not in any circumstances seek to recover monies from the investor beyond the amount paid up on the units. With a limited partnership, a degree of due diligence needs to be undertaken to ensure that all the necessary registrations and filings required to confer limited liability on limited partners have been effected and will be maintained. The risk, of course, is that filings may well be the responsibility of a shell general partner and, in default of such filings, the limited partners may be treated as general partners with ensuing unlimited liability. This is usually dealt with by taking a legal opinion from the relevant jurisdiction. Another issue relating to limited partnership structures is that if the investor concerned wishes to take some involvement in the management of the fund (eg the investor wishes to be consulted and/or to have some role in supervising the management of the funds portfolio) then, again, that gives rise to the possibility of an argument that the investor concerned will be treated as a general partner rather than a limited partner notwithstanding any registrations.
Finally, with all offshore limited partnerships, there remains the possibility that in any jurisdiction in which the fund is active, the courts of the jurisdiction may not necessarily recognise the limited liability nature of the partnership interest without some form of registration in the jurisdiction concerned. While this has been a theoretical rather than an actual risk to date, there remains some legal uncertainty over this point. As a result of the above, all things being equal, UK investors would tend to prefer investment through a corporate vehicle rather than a limited partnership vehicle.

\section{Umbrella structures: contagion risks}

Where a fund manager offers a series of hedge fund products, an investor needs to be comfortable that the failure of one of those products could not affect other products. This issue arises in relation to funds structured as 'umbrella funds' or 'multi-class funds'. With these structures, the one corporate entity will maintain a series of different hedge fund portfolios and issue to investors different classes of shares with each class corresponding to a particular hedge fund portfolio. There are many advantages to the manager of a hedge fund with such structures and, of course, some of these benefits indirectly assist investors. In particular, they reduce the overhead cost of the product, and assist the manager in being able to launch further product quickly and cost-effectively. They also introduce a conformity of style across the provider's product range or tailor a fund to the needs of a particular investor group. The inherent risk with umbrella structures is that they are provided by one legal entity. If, therefore, there were insufficient assets in any particular fund to discharge the liabilities attributable to that fund, the aggrieved creditors could choose to pursue an action against the 
company generally and to enforce it against any other assets of that company. When investing in umbrella structures, investors need to undertake a further layer of due diligence to gain comfort that the risk of such cross liability or 'contagion' from one fund to another is sufficiently remote so as not to create undue risk for the investor. This may involve undertaking some due diligence on the investment policies and strategies of other funds within the umbrella. There are a number of other basic protections which can be built into such structures. The first is that each fund should be traded through an SPV (itself either a limited liability company or limited partnership) so that any counterparty would be dealing with that SPV rather than the umbrella vehicle itself. Secondly, parties contracting with the umbrella vehicle or any of its sub-funds should expressly agree that they would not in any circumstances have recourse to the assets of any of the other sub-funds. For example, any prime broker acting in such capacity in respect of any particular sub-fund should agree that it would not in any circumstances seek recourse against assets of any other sub-fund in respect of liabilities of the former sub-fund.

It should also be pointed out that in the Cayman Islands and certain other jurisdictions, provision has been made in law for the creation of 'protected cell' companies (PCCs). ${ }^{6}$ These are umbrella fund companies where local law recognises the segregated nature of the different portfolios and confers limited liability on each cell thus, in theory, removing the cross liability risk. Reliance on PCC structures should be cautioned as any legal action is likely to occur not in the jurisdiction of domicile but in the jurisdiction where the assets and creditors are located (eg the UK or USA), and there is no precedent for whether or not the courts of those other countries might recognise the limited liability of any particular fund or cell.

\section{UK tax issues}

Cayman and other offshore-based hedge funds will always hold themselves out as not being resident in the UK for tax purposes and will also hold out that any UK investment manager would be able to avail itself of the so-called 'investment management exemption'. ${ }^{7}$ In fact, the issue of tax residence and the availability of the exemption are matters of fact which can only be determined in relation to the way in which the hedge fund and manager conduct their respective affairs. The risk is that if, in fact, the fund conducts itself in a way that made it resident in the UK for tax purposes, the fund itself could be subject to a significant UK tax charge. It is very important that the composition of the board of directors and the procedures adopted by the fund and the manager are compatible with being non-resident and with the manager obtaining this investment management exemption. It is suggested that often insufficient care and attention are given to this area by hedge funds and their managers with the result that there is a greater potential exposure than should be the case. The due diligence of any pension fund investor should therefore include satisfying themselves as to the residence of the fund, and indeed, the applicability of the 'investment management exemption'.

By way of an example, to be able to demonstrate that a Cayman hedge fund is not UK resident, it is important to be able to show that the 'central management and control' of a hedge fund is not effected from the UK. This would typically be done by showing that the fund's board of directors comprised a majority of non-UK persons who met 
regularly at a non-UK location and made real management and control decisions at those meetings. It is all too common, in fact, for the board of a hedge fund to comprise a representative of the fund manager plus a couple of 'offshore' directors who are of little real substance and who, perhaps, act as 'directors' for a large number of other hedge funds. In many cases meetings are only effected on the telephone or, worse still, some are merely seen as a paper exercise. All significant decisions are really made in the UK by the UK fund manager with the board of directors merely rubber-stamping the decisions and not engaging in any material discussion and/or debate. This is a common scenario and carries with it a material risk that the hedge fund could subject itself to an unnecessary and material UK tax charge.

\section{Corporate governance}

Related to the above point is the issue of corporate governance. Investors should consider the extent to which they require independent oversight of funds in which they invest. Traditional unit trusts would typically have an independent trustee; investment trusts have an independent board of directors; and authorised open-ended investment companies have an independent depository. These independent persons offer some degree of supervisory power and discretion over the fund manager. The practice with hedge funds is much less uniform. Some hedge funds, particularly those that are stock exchange listed, offer an independent board of directors that will take a genuinely supervisory role. All too often, however, hedge funds will not have any genuinely independent directors. Typically the board may comprise representatives of the fund manager and/or representatives of the offshore administrator. It is suggested that such directors will often not have the time, capability or inclination to act against the interests of the fund manager in protecting investors' interests.

\section{Investment terms}

\section{General: Contracting parties}

This section of the paper attempts to identify and briefly summarise some of the more contentious legal terms on which hedge fund investments are made; although it is beyond its remit to deal with the commercial terms such as the management and performance fees. The first point which needs to be made is that some attention needs to be given as to the identity of the contracting parties and the governing laws to be applied to the arrangements. Clearly the hedge fund itself would typically enter into basic contractual obligations with investors, eg relating to the issue and redemption of shares. These may be express obligations in subscription documentation and/or comprise representations contained in the hedge fund's prospectus or other offering document. Institutional investors will generally also seek some direct comfort from the manager/investment manager of the hedge fund, very often in a separate agreement or side letter. Clearly some undertakings, warranties, etc, are more appropriately given by the manager or investment manager than by the hedge fund itself. This is partly because some of the warranties and undertakings may relate directly to the activities of the fund manager, but also because the investor would wish to enforce any right against the manager/investment manager rather than against the fund itself in which, of course, the investor has an economic interest. Investors should also be careful to ensure that the contracting 
party comprises the real manager/investment manager and not just a poorly capitalised offshore 'shell'. For small and/or start up hedge fund managers, consideration needs to be given to taking some undertakings, warranties, etc, directly from the key individuals themselves to maintain maximum protection.

As to the governing law, UK-based investors are likely to prefer that English law apply as far as possible. It is likely that such investors and their legal teams will be more familiar with and hence have a preference for English law contracts despite the common law similarities of Cayman law and English law. In particular, if the worst happens and litigation becomes necessary, UK investors are likely to feel better protected if they can use their existing English advisers and seek redress through the English courts, rather than be subject to the lesser known courts, and necessarily small pool of lawyers from which to choose, in the Cayman Islands.

\section{Rights of redemption}

Typically the offering memorandum of a hedge fund will set out the basic monthly, quarterly or other redemption rights. In the small print there will invariably be powers given to the hedge fund to suspend redemptions in certain circumstances and/or limit redemptions or the implementation thereof. Very often such rights are taken by the hedge fund with the best of intentions; ie to protect ongoing investors in the case of large-scale redemptions and to ensure that the fund can arrange an orderly disposition of its positions if it is required to raise liquidity to fund redemptions or to suspend redemptions in times of extreme market conditions. Investors must understand and be comfortable with the detailed provisions relating to notice periods and all redemption limits or restrictions. Consideration also needs to be given to whether additional comfort should be sought from the hedge fund or its manager relating to the application or implementation of rights of suspension or other restrictions being imposed. At the very least there should be an obligation on the hedge fund not to exercise any such rights in a capricious or discriminatory manner.

\section{Transparency and supply of information}

Very often there is reluctance on behalf of the fund manager to provide detailed information on portfolio composition. Such information is sometimes regarded as proprietary. The investor needs to determine, however, what degree of portfolio information it requires to be comfortable. Likewise investors should seek transparency as to the operation of the hedge fund as a collective investment scheme and hence be promptly notified of any changes relating to the structure of the hedge fund, its service providers, directors, management or other activities. In negotiating what information an investor wishes to receive and when, an investor should have some regard to the issue of whether or not the provision of information by a hedge fund manager could, in certain circumstances, make the investor an 'insider' either in relation to shares in the hedge fund itself or in relation to the hedge fund's investments.

\section{Most favourable treatment undertaking}

Where an institution's investment in a particular hedge fund is significant for the hedge fund manager in terms of its amount (or, perhaps, in terms of the investor's willingness to commit to a longer than normal investment period), it 
is not uncommon for such investors to be able to negotiate special terms with regard to management and performance fees, the supply of information, transparency and other preferential rights. In obtaining such preferential rights, it is important to ensure that, where the hedge fund is listed, such rights are granted by the manager and not by the fund itself, which would be under an obligation to ensure equality of treatment to all shareholders. In such circumstances, where an investor sees himself/herself as a 'cornerstone' investor in a particular product, it would be useful for the investor to take an undertaking from the fund and manager that there are no other investors, and no further investors will be admitted who have invested on terms that are preferable to those being offered to this investor.

\section{Investment restrictions and limitation: Stop loss limits}

It is common practice for the investment policy of a hedge fund to be described in its offering document in the widest terms. The terms of the prospectus will often be very general and few or no investment restrictions or limits will be included. Fund managers would then explain in more detail to the potential investors the investment process and parameters which are intended to apply. While the prospectus is drafted in such a wide form, it could be difficult for an investor to rely - from a legal perspective - on the more detailed description of the investment policy, which had been explained to them perhaps in a presentation or on the telephone. For these reasons, it is not uncommon for investors to seek to define an investment policy somewhat more closely than it has been defined in the prospectus. This may include negotiating maximum long and short exposures, counterparty risk limits, and perhaps the imposition of stop loss limits.

\section{Best execution/softing and conflicts of interest}

Again in the interests of transparency, investors need to consider ensuring that the fund manager adopts a policy of best execution or, at least, is completely transparent as to any soft commission or other arrangements which they may operate with selected brokers. This would be the case particularly where the manager is not subject to appropriate rules of the UK Financial Services Authority (FSA) or equivalent regulatory bodies. The existence of soft commission arrangements and/or broker rebates can significantly hide the true level of management remuneration for a fund and investors should seek transparency in this area. Other potential areas of conflict of interest should be examined during the due diligence process and transparency should be sought from the manager on an ongoing basis to avoid any misunderstandings developing at a later stage. The potential for conflicts of interest to arise increases where the hedge fund manager also manages long only funds and/or is part of a larger financial services group.

\section{Key personnel}

Where an investor is investing in a hedge fund on the strength of its assessment of a particular individual or individuals, it is important to ensure, as far as possible, that those individuals will be applying themselves to the relevant hedge fund to the appropriate extent and/or, at the very least, the investor is given sufficient prior notification of any departure by an individual so that, if they so wish, they would be able to effect a timely redemption. 


\section{Appropriate standard of care}

Negligence has always been the appropriate standard of care under the English law of tort and contract and generally is adopted by the financial services industry. Perhaps because of the US influence, however, the standard of care sought to be adopted by many fund managers in relation to hedge fund products is 'gross negligence.' It is beyond the scope of this paper to consider the English law distinction (if any) between 'negligence' and 'gross negligence' but as far as investors are concerned, it is suggested that they should be very careful about accepting a standard of care which is less than normal market practice. In particular, pension fund managers and trustees themselves are likely to be subject to a standard of care which equates to 'negligence' and if they appoint a third party provider who adopts a lesser standard of care it is suggested that the trustees/managers could find themselves exposed in the event that the pension fund lost money as a result of the actions of a fund manager who was negligent, but not so negligent as to constitute gross negligence.

\section{Liability caps and insurance coverage}

Investors should look carefully and critically at any liability caps included in investment management contracts by hedge fund managers, particularly in the case of small and start-up hedge funds. Likewise as a matter of due diligence, it is suggested that the investor should consider the insurance position of the hedge fund manager and regard should be had to the level of insurance coverage when considering the amount of any investment in a hedge fund. Other areas of contention are likely to be similar to those that arise in respect of exclusion and liability clauses generally; for example, should there be an indemnity from the hedge fund in favour of the manager and what should its scope be? Should the manager assume responsibility for the actions of any investment adviser or delegate that it appoints? For which costs and out-of-pocket expenses should the manager be indemnified?

\section{The future}

As will be appreciated from the above, many of the issues arising from an institution investing in a hedge fund do so because the market is still at a developmental stage and because the funds themselves currently tend to be completely unregulated. Hedge funds are coming under greater scrutiny by regulators throughout the world and it can be anticipated that increased regulation of the hedge fund industry will follow in due course. Provided that this regulation is not so prescriptive as to stifle development of the hedge fund market, it would be hoped that the new regulations could lead to the development of market norms and some regulatory protection for pension fund and other institutional investors. In May of 2003, the FSA published a consultation paper $^{8}$ containing proposals for the introduction of a new type of UK-domiciled vehicle which would be authorised by the FSA and available only to intermediate customers and market counterparties. The objective behind the introduction of the new vehicle would seem to provide a halfway house between retail funds and wholly unregulated funds. Initial indications suggest that the new vehicle could be suitable for use as a hedge fund. The proposal still needs some degree of fleshing out and we await with interest the Inland Revenue's proposed tax treatment of these vehicles. If they could become a viable onshore alternative to 
offshore hedge funds this may provide a hedge fund vehicle with the potential to meet investors' needs rather more closely than the current completely unregulated product. In January of this year, the European Parliament passed proposals aimed at introducing a Europe-wide version of hedge funds and other alternative investment vehicles. ${ }^{9}$ Again, the proposals envisage the creation of a regime within the EU to provide a more supervised environment from which sophisticated alternative investment vehicles can operate. This proposal also has the potential to provide a suitable vehicle for hedge fund investment by pension funds and other institutions. The European Parliament proposals are now up for consideration by the Commission and legislation is not expected for some time.

\section{References}

1 Source: The Hedge Fund Association.

2 Financial Services and Markets Act, 2000, s. 235.

3 Financial Services Authority Discussion Paper 16 (DP16).

4 Financial Services and Markets Act 2000 (Promotion of Collective Investment Schemes) (Exemption) Order, 2001, Reg. 2(1).

5 Financial Services Authority Interim Prudential Sourcebook: chapter 4, 'Insurers' (IPRU (INS)).

6 For example, see The Companies Law (2001) Second Revision of the Cayman Islands.

7 Finance Act, 1995, s. 127.

8 Financial Services Authority Consultation Paper 185 (CP185).

9 Directive 2001/108/EC (final) Art. 2 and European Parliament Motion for a Resolution on the Future of Hedge Funds and Derivatives (2002/2082(INI)). 